\title{
Survival Rates and Stopover Persistence of American Woodcock Using Cape May, New Jersey, during Fall Migration
}

\author{
DANIEL G. MCAULEY, ${ }^{1}$ U.S. Geological Survey, Patuxent Wildlife Research Center, Orono, Maine, USA \\ GUTHRIE ZIMMERMAN, U.S. Fish and Wildlife Service, Division of Migratory Bird Management, Sacramento, \\ California, USA
}

BRIAN B. ALLEN, University of Maine, Department of Wildlife, Fisheries, and Conservation Biology, Orono, Maine, USA

CHRIS DWYER, U.S. Fish and Wildlife Service, Region 5 Migratory Bird Program, Hadley, Massachusetts, USA

THOMAS R. COOPER, U.S. Fish and Wildlife Service, Region 3 Migratory Bird Program, Bloomington, Minnesota, USA

\begin{abstract}
Cape May, New Jersey is an important stopover area for American woodcock (Scolopax minor; hereafter woodcock) during fall migration along the Atlantic Coast of the United States. Previous research has indicated that many woodcock stop at Cape May prior to crossing Delaware Bay; however, little is known about survival of woodcock while using Cape May. To better understand woodcock survival on Cape May during fall migration and to estimate emigration rates for woodcock migrating through Cape May, we captured and marked a total of 271 woodcock with VHF transmitters and radio-tracked them weekly from November through early January 2010--2013. Of the 271 marked woodcock, our radio-tracking efforts indicated that 131 migrated from Cape May, 57 remained on Cape May, 72 died, and 11 were censored. We used a multi-state model within Program MARK to estimate weekly survival and emigration probabilities for marked woodcock. Our best-supported model indicated that survival rate varied by year, but was constant by week within years. Weekly survival rate estimates ranged from $0.894(95 \% \mathrm{CI}=0.834-0.934)$ in 2010 to $0.962(95 \% \mathrm{CI}=0.928-0.981)$ in 2011, which equates to a 9-week period survival rate ranging from $0.365(95 \% \mathrm{CI}=0.185-0.545)$ to $0.706(95 \% \mathrm{CI}=0.541-$ 0.870 ), respectively. The 2010--2011 field season was marked by several large snowstorms during which a large percentage of marked woodcock died, whereas the other 3 years had more mild conditions and higher woodcock survival rates. Our best-supported model indicated that weekly emigration rates varied by year and week, with each year showing a different pattern of emigration from Cape May. Survival and emigration information will be useful in the development of future demographic-based population models for woodcock migrating along the Atlantic Coast.
\end{abstract}

Proceedings of the American Woodcock Symposium 11: 146-153

KEY WORDS: American woodcock, Cape May, emigration, migration, stopover, survival

The Cape May Peninsula in southern New Jersey has long been recognized as important to migrating American woodcock (Scolopax minor, ; hereafter woodcock). Cape May forms a natural funnel where woodcock migrating along the East Coast of the U.S. concentrate prior to crossing Delaware Bay during fall migration. During a 5-year study from 1968 to 1972, Krohn et al. (1974) banded over
2,200 woodcock on Cape May in the fall. Band recoveries from their work indicated that woodcock migrating through Cape May wintered on the coastal plain of Virginia and North Carolina and originated from New England and eastern Canada. All recoveries, both direct and indirect, were from within the area defined as the Eastern Woodcock Management Region (Cooper and

1 email: dmcauley@usgs.gov 
Kelley 2010). Although the work by Krohn et al. (1974) provided information on the importance of Cape May to woodcock, information on how long woodcock stayed in Cape May or their survival there is unknown.

To date, most published estimates of period-specific woodcock survival rates, using radio telemetry techniques, have focused on estimating survival rates during the breeding season (e.g., Longcore et al. 1996, 200o; McAuley et al. 2010; Derleth and Sepik 1990) or during the winter (Krementz and Berdeen 1997, Krementz et al. 1994, Pace 2000). Data are lacking for woodcock survival rates during migration (Longcore et al. 1996, D.J. Case and Associates 2010); a period when woodcock may have higher mortality risks because they are transient, and at least for first-time migrants, are using new, unfamiliar areas as they migrate. Information about survival rates during migration comes primarily from banding data and telemetry studies (Longcore et al. 1996, 200o), with additional information coming from assessments of the effect of hunting on survival rates coinciding with the start of fall migration in the Northeast (McAuley et al. 2005) and Midwest U.S (Bruggink et al. 2013). Although these studies of hunting effects on survival rates extended partially into the fall migration period, both ended in November and there are no assessments of survival rates later in the fall at important mid-latitude locations such as on the Cape May Peninsula.

Because woodcock populations have experienced long-term declines (Seamans and Rau 2016), managers need to better understand what portion of the woodcock's annual cycle may be limiting populations (D.J. Case and Associates 2010). Determining period survival rates using radio telemetry may help to better understand factors limiting woodcock populations and be useful for deriving population models that include the entirety of the annual cycle for woodcock. As such, the primary objectives of our study were to estimate survival rates for woodcock using Cape May during late fall/early winter and to better understand emigration patterns for woodcock migrating through Cape May, New Jersey.

\section{Study Area}

We conducted our study in Cape May County, New Jersey USA $\left(39.1521^{\circ} \mathrm{N},-74.8065^{\circ} \mathrm{W}\right)$. Cape May County is a peninsula at the southern end of New Jersey separating Delaware Bay from the Atlantic Ocean (Fig. 1). The landscape is a composite of active and abandoned farm fields, woodlands, and suburban and commercial development (Allen 2017). Topography is relatively flat, (average elevation of $14 \mathrm{~m}$ above sea level, $\mathrm{SD}=11.1 \mathrm{~m}, \max =60.0 \mathrm{~m}$ ), with oak (Quercus spp.)-pine (Pinus spp.) forest on welldrained sites, whereas and poorly drained sites are dominated by maple (Acer spp.) and sweetgum (Liquidamber stryaciflua) forests. We captured woodcock on properties

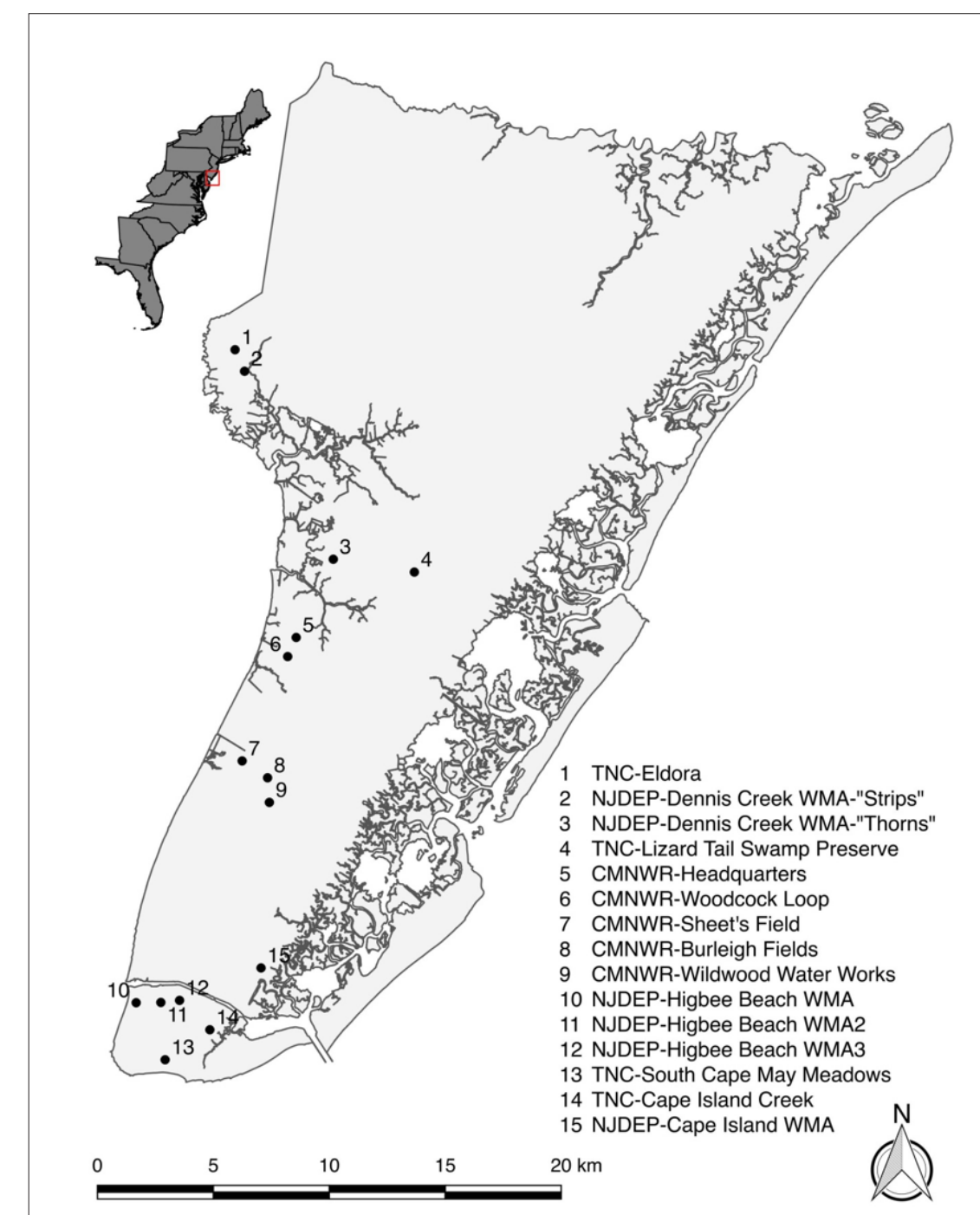

Figure 1. Study area and trapping locations (numbered sites) where American woodcock were radio-marked and monitored during migration at Cape May, New Jersey, 2010-2013. TNC = The Nature Conservancy, NJDEP = New Jersey Department of Environmental Protection, and CMNWR = Cape May National Wildlife Refuge. 
owned and managed by the Cape May National Wildlife Refuge (CMNWR), New Jersey Division of Fish and Wildlife (NJDFW), and the New Jersey Chapter of The Nature Conservancy (TNC) (Fig. 1). State, federal, and municipality lands accounted for most of the land ownership on Cape May (Cape May County records); but because woodcock also used lands in private ownership, we extended our work onto these lands when radio-tagged woodcock left state, federal, or municipality land holdings.

\section{Methods}

\section{FIELD METHODS}

We captured and radio-marked woodcock at Cape May during the fall and early winter period from 2010 through 2013. We began fieldwork during the last week of October and ended radio tracking marked woodcock from mid-January to early February each year depending on funding and field technician availability. As such, we only used data from a 9-week period (1 November until early January) each year to estimate survival and emigration rates because we had consistent data for this period during all 4 years of our study.

We captured woodcock on fields at night using night-lighting techniques (Rieffenberger and Kletzly 1967) and fitted individuals with a uniquely numbered U. S. Geological Survey leg band and an approximately 4.0-g VHF radio transmitter (Advanced Telemetry Systems, Inc., Isanti, MN) using methods described by McAuley et al. (1993). We aged woodcock as hatch-year (HY) and after hatch-year (AHY), determined sex using wing characteristics (Martin 1964, Mendall and Aldous 1943), and measured mass $( \pm 1 \mathrm{~g})$ and bill length $( \pm 1 \mathrm{~mm})$ for each individual. We used bill length to aid in sex determination (Mendall and Aldous 1943). We radio-marked between 50 and 80 individuals each year, and staggered radio-tag deployment to about 10 woodcock per week to maximize temporal coverage throughout the migration period. We deployed transmitters in this manner to maintain adequate sample sizes and account for the constant turnover of woodcock migrating through our study area. Cape May is best known as a migratory stopover site for woodcock and other birds, but woodcock breed and remain on the peninsula year- round (https:// www.timberdoodle.org). As such, we searched the study area in early March each year to determine if any woodcock in our marked sampled remained on Cape May going into the breeding season. The transmitters we used lasted $\geq 6$ months, so we should have detected radio-marked woodcock if they remained on Cape May in early March.

We used a vehicle with a 6-element Yagi antenna mounted on the roof to search for radio-tagged woodcock daily. We attempted to locate each marked woodcock every 2 days on foot by homing to it without flushing using a three-element Yagi (Advanced Telemetry Systems, Isanti,
MN) or H-style antenna (Telonics Inc., Mesa AZ) and handheld receiver. We established a woodcock's status (i.e., alive, dead, or not encountered) during these observations. For woodcock found dead, we determined the cause of death based on a post-mortem examination and classified the cause of death as avian predation (carcass in tree, bill marks on harness, feathers plucked around the carcass), mammalian predation (teeth marks on the harness, most of the carcass eaten), or unknown mortality. We recorded presence/absence of a woodcock in the study area on days that we did not home in on an individual. When we did not detect radio-tagged woodcock, we systematically searched the study area using a vehicle with a mounted antenna and receiver, and we continued monitoring for the presence of those individuals for the duration of the field season. If we did not relocate a marked individual during consecutive 2-day survey periods, we assumed the bird migrated from Cape May. To test this assumption, we conducted 2 aerial reconnaissance flights over Delaware, the Eastern Shore of Maryland, and northern Virginia on 22 December 2011 and 4 January 2012 to search for marked woodcock.

All procedures involving woodcock were approved by the U.S. Geological Survey Patuxent Wildlife Research Center Animal Care and Use Committee.

\section{STATISTICAL METHODS}

We used multi-state live-recapture models in Program MARK (White and Burnham 1999, White et al. 2006) to estimate survival and emigration rates for woodcock using Cape May as a stopover site during fall migration. Multistate models allow estimation of survival (S), live-recapture $(\mathrm{p})$, and transition probabilities $(\psi)$ between states. For our analysis, we considered 2 states: within the study area ( $\mathrm{C}$ for Cape May) and outside the study area ( $\mathrm{O}$ for outside the study area). Our primary interest was estimating survival rates of woodcock spending time in Cape May (SC) and trends in emigration rates from Cape May $\left(\psi^{\mathrm{CO}}\right)$. Because all woodcock in our study were equipped with radio transmitters, we assumed that detection rates were 1 within the Cape May study area $\left(\mathrm{p}^{\mathrm{C}}=1\right)$ and that we knew with certainty when birds left the study area (i.e., if a radio signal was not detected, we assumed the individual emigrated from the study area and migrated south; $\mathrm{p}^{\mathrm{O}}=1$ for the first interval a woodcock was not detected). We also assumed that once woodcock emigrated from the study area, they could not return $\left(\psi^{\mathrm{OC}}=0\right)$, and censored them from the analysis for the remainder of that season. .

Our primary goal for this analysis was to explore annual patterns in survival rates and within- and amongyear patterns in emigration rates. Therefore, we considered 2 alternative patterns in survival rates: constant among years $\left(S .^{C}\right)$ and categorical year effects $\left(S_{y}^{C}\right)$. Because we only had 4 years of data and resulting small numbers of 
woodcock in any given week, we did not evaluate trends in weekly survival rates among years. As described above, we tracked marked woodcock weekly and organized the capture histories into 9 within-season, week-long periods. We considered 4 alternative temporal models for transition probabilities: constant among periods $\left(\psi{ }^{\mathrm{CO}}\right)$;, categorical effects of period $\left(\psi_{t}^{\mathrm{CO}}\right)$,; linear trend over the 9 periods $\left(\psi_{T}^{\mathrm{CO}}\right)$; , and quadratic trend over the 9 periods $\left(\psi_{T^{2}}^{\mathrm{CO}}\right)$. We included each of these 4 alternatives with and without interactive effects of year: $\psi_{y}^{\mathrm{CO}}, \psi_{y^{*} t}^{\mathrm{CO}}, \psi_{y^{*} T}^{\mathrm{CO}}$, and $\psi_{y^{*} T^{2}}^{\mathrm{CO}}$. We included these 8 transition models with the 2 alternative models of survival rates for a total of 16 models. We ranked the 16 models using a sample-size adjustment of Akaike's Information Criteria $\left(\mathrm{AIC}_{\mathrm{c}}\right.$; Burnham and Anderson 2002) and used model weights to estimate model-averaged estimates of weekly survival and emigration probabilities. We determined the 9-week period survival rate (PSR) for each year by taking the weekly survival rate and raising it to the 9th power, with the SE of PSR determined using the delta method (Powell 2007).

A secondary objective of this analysis was to explore potential effects of age and sex on survival rates of woodcock stopping on Cape May. We used the top-ranked model describing trends in survival rates to estimate sur-

Table 1. Cohort summary for 271 woodcock VHFtracked on the Cape May Peninsula of New Jersey, 2010-2013 (HY = Hatch Year, AHY = After Hatch-Year).

\begin{tabular}{lrrrrr}
\hline & \multicolumn{2}{c}{ Male } & \multicolumn{2}{c}{ Female } \\
Year & HY & AHY & HY & AHY & Total \\
\hline 2010 & 25 & 5 & 22 & 6 & 58 \\
2011 & 23 & 7 & 19 & 4 & 53 \\
2012 & 50 & 2 & 22 & 6 & 80 \\
2013 & 44 & 13 & 19 & 4 & 80 \\
Total & 142 & 27 & 82 & 20 & 271 \\
\hline
\end{tabular}

Table 2. Fates of 271 American woodcock VHF-tracked on the Cape May Peninsula of New Jersey, 2010-2013 Table 1. Cohort summary for 271 woodcock VHF-tracked on the Cape May Peninsula of New Jersey, 2010-2013 (HY = Hatch Year, AHY = After Hatch-Year).

\begin{tabular}{crrrrrrr}
\hline & \multicolumn{3}{c}{ Mortality } & & & & \\
\cline { 2 - 5 } Year & Unknown & Avian & Mammalian & Censored & Migrated & Stayed $^{\text {a }}$ & Total \\
\hline 2010 & 22 & 0 & 0 & 2 & 30 & 5 & 59 \\
2011 & 1 & 5 & 3 & 1 & 19 & 24 & 53 \\
2012 & 7 & 16 & 4 & 4 & 33 & 15 & 79 \\
2013 & 2 & 8 & 4 & 4 & 49 & 13 & 80 \\
Total & 32 & 29 & 11 & 11 & 131 & 57 & 271 \\
\hline
\end{tabular}

a Were alive and still on Cape May at the conclusion of the tracking period in early January each year. vival rates based on sex and age (hatch year versus after hatch-year). We compared additive versus interactive effects of sex on survival rates, but only considered additive effects of age because the sample size of after hatchyear woodcock was too small to estimate effects among years. The findings and conclusions in this article are those of the authors and do not necessarily represent the views of the U.S. Fish and Wildlife Service and the U. S. Geological Survey.

\section{Results}

During our 4 field seasons (2010-2013), we radio-marked and tracked 271 woodcock during the 9 -week periods from 1 November through early January. The sample included 142 hatch-year males, 27 after hatch-year males, 82 hatchyear females, and 20 after hatch-year females (Table 1 ). The fates of marked woodcock in our sample included 72 that died, 57 that remained on Cape May and were still alive at the end of our tracking period, 131 that migrated, and 11 that were censored (Table 2). The censored woodcock included 9 that slipped their transmitter harness and 2 that died due to their bill getting stuck in the transmitter harness. We could not determine the cause of mortality for 32 woodcock, whereas predation was the likely cause of death for 40 individuals (Table 2).

We did not find any live birds remaining from our marked sample when we searched the study area in the beginning of March each year. During the 2 reconnaissance flights south of our study area, we located 6 birds;: 3 on the Eastern Shore of Maryland, 1 on the Eastern Shore of the Virginia National Wildlife Refuge, and 2 in northern Virginia. Although we located only 6 woodcock during these flights, locations of these 6 woodcock provided support for our assumption that woodcock not relocated on Cape May had migrated south of our study area.

Our AIC best-supported model (Table 3) indicated that survival rates were constant by week but varied by year and that weekly emigration rates followed different quadratic trends among years. Weekly survival rates ranged from $0.894(95 \%$ $\mathrm{CI}=0.834-0.934) \mathrm{in}$ 2010 to 0.962 (95\% CI $=0.928-0.981)$ in 2011 (Fig. 2), which equates to a 9-week period survival rate (PSR) ranging from 0.365 (95\% CI = $0.185-0.545)$ to 0.706 $(95 \% \mathrm{CI}=0.541-0.870)$, respectively (Table 4). 
Our best-supported model indicated that weekly emigration rates varied by year and week with each year exhibiting a different pattern of emigration from Cape May (Fig. 3). This model indicated that emigration rates were low and relatively constant throughout most of the study, with a rapid increase during the last few weekly periods in 2010. In 2011, emigration rates were close to zero the first few weekly periods, followed by a peak during period 6 and then a decline towards the end of the season. The temporal trend in emigration rates during 2012 was similar to the pattern observed in 2010, whereas the peak emigration rate appeared to be during the first few weekly periods in 2013. Overall, emigration rates ranged from none up to a one-third of woodcock leaving in a given week.

Because the survival rate model that included an interaction between sex and year on survival rates did not converge, we considered age and sex as additive effects to year to assess whether those variables improved model fit and to estimate any potential effects of those variables. Including sex ( $\triangle$ AICC $=1.51)$ and age $(\triangle$ AICC $=1.70)$ did not improve the fit of the best-supported model. Parameter estimate for the effect of sex indicated that males had slightly higher survival rates than females and the estimate for age indicated that after hatch-year woodcock had slightly higher survival probabilities than hatch-year woodcock. However, confidence intervals for both parameter estimates broadly overlapped zero, indicating that the effects of these variables were weak $\left(\beta_{\text {sex }}=0.28,95 \% \mathrm{CI}=-0.45,1.0\right.$; $\left.\beta_{\text {age }}=0.32,95 \% \mathrm{CI}=-1.40,0.76\right)$.

\section{Discussion}

Our period survival rate estimates (PSR) for November through early January ranged from 0.365 (95\% $\mathrm{CI}=0.185-0.545)$ to $0.706(95 \% \mathrm{CI}$ $=0.541-0.870)$. These estimates represent the first empirical survival rate estimates for woodcock during the late fall/early winter portion of the annual cycle. Previous estimates (e.g., Longcore et al. 1996, 2000) for this period were derived using annual survival estimates from banding data combined with PSRs estimated with telemetry data for other periods of the year (e.g., breeding season, post-breeding, wintering). Longcore et al. (1996) derived a PSR of 0.853 for after hatch-year male woodcock during mid-October to mid-December, whereas Longcore et al. (2000) derived a PSR of 1.045 for after hatch-year females during the same period. Both these estimates were higher than our estimates and are likely biased high, especially the PSR for after hatch-year females (1.045), which is unrealistic,

Table 3. Relative rankings of 16 a priori models of weekly survival (S) and emigration $(\psi)$ probabilities for radio-marked American woodcock using the Cape May Peninsula of New Jersey during late fall, 2010-2013. Data include differences in Akaike information criteria $\left(\triangle \mathrm{AIC}_{\mathrm{c}}\right), \mathrm{AIC}_{\mathrm{c}}$ weights (wi), number of model parameters $(\mathrm{K})$, and model deviance.

\begin{tabular}{|c|c|c|c|c|c|}
\hline Model $^{\mathbf{a}}$ & $\mathrm{AIC}_{\mathrm{c}}$ & $\Delta \mathrm{AIC}_{\mathrm{c}}$ & $\mathrm{AIC}_{\mathrm{c}} \mathrm{w}_{\mathrm{i}}$ & $\mathbf{K}$ & Deviance \\
\hline$S_{y}^{C} \psi_{y * T^{2}}^{C O}$ & 1135.65 & 0 & 0.72 & 16 & 1103.14 \\
\hline$S_{y,}^{C} \psi_{y * t}^{C O}$ & 1138.15 & 2.50 & 0.21 & 36 & 1063.62 \\
\hline$S^{C}, \psi_{y * T^{2}}^{C O}$ & 1140.93 & 5.28 & 0.05 & 13 & 1114.59 \\
\hline$S_{\cdot}^{C}, \psi_{y * t}^{C O}$ & 1143.20 & 7.55 & 0.02 & 33 & 1075.07 \\
\hline$S_{y,}^{C} \psi_{y * T}^{C O}$ & 1148.13 & 12.48 & 0 & 12 & 1123.84 \\
\hline$S^{C}, \psi_{y * T}^{C O}$ & 1153.45 & 17.81 & 0 & 9 & 1135.29 \\
\hline$S_{y,}^{C} \psi_{y}^{C O}$ & 1173.50 & 37.85 & 0 & 8 & 1157.36 \\
\hline$S_{y,}^{C} \psi_{T^{2}}^{C O}$ & 1174.25 & 38.60 & 0 & 7 & 1160.14 \\
\hline$S_{y,}^{C} \psi_{T}^{C O}$ & 1177.65 & 42.00 & 0 & 6 & 1165.57 \\
\hline$S_{\cdot}^{C}, \psi_{y}^{C O}$ & 1178.87 & 43.22 & 0 & 5 & 1168.82 \\
\hline$S^{C}, \psi_{T^{2}}^{C O}$ & 1179.63 & 43.99 & 0 & 4 & 1171.60 \\
\hline$S^{C}, \psi_{t}^{C O}$ & 1181.27 & 45.62 & 0 & 12 & 1156.98 \\
\hline$S_{\cdot,}^{C} \psi_{T}^{C O}$ & 1183.05 & 47.40 & 0 & 3 & 1177.03 \\
\hline$S_{y,}^{C} \psi^{C O}$ & 1184.13 & 48.48 & 0 & 5 & 1174.08 \\
\hline$S_{\cdot}^{C}, \psi_{t}^{C O}$ & 1186.60 & 50.95 & 0 & 9 & 1168.43 \\
\hline$S_{\cdot}^{C}, \psi^{C O}$ & 1189.54 & 53.89 & 0 & 2 & 1185.53 \\
\hline
\end{tabular}

a $\mathrm{S}=$ survival, $\psi=$ emigration, $y=$ year effects, $t=$ categorical period effect, $T=$ linear trend among periods, $\mathrm{T}^{2}=$ quadratic trend among periods, $\mathrm{C}=$ Cape May, $\mathrm{CO}=$ emigration from Cape May to outside of Cape May study area, and ${ }^{*}=$ interactive effect between parameters.

Table 4. Weekly survival rate estimates, standard errors (SE), 95\% confidence interval (CI), and 9-week period survival rate estimates (PSR), standard errors (SE), and 95\% confidence interval (CI) for American woodcock using the Cape May Peninsula of New Jersey, 2010-2013.

\begin{tabular}{ccccccc}
\hline Weekly & & & & & \\
Year & Survival & SE & $\mathbf{9 5 \%}$ CI & PSR $^{\mathrm{a}}$ & SE(PSR) & 95\% CI PSR \\
\hline 2010 & 0.894 & 0.0250 & $0.834-0.934$ & 0.365 & 0.092 & $0.185-0.545$ \\
2011 & 0.962 & 0.0127 & $0.928-0.981$ & 0.706 & 0.084 & $0.541-0.870$ \\
2012 & 0.948 & 0.0117 & $0.919-0.967$ & 0.618 & 0.069 & $0.484-0.753$ \\
2013 & 0.954 & 0.0124 & $0.922-0.973$ & 0.655 & 0.077 & $0.504-0.805$ \\
\hline
\end{tabular}

a PSR = November through early January; calculated by taking weekly survival to the 9 th power. SE of PSR was calculated using the delta method

(Powell 2007), where var $($ PSR $)=9^{2} W S R^{(9-1)^{* 2}} \times \operatorname{var}(W S R)$. 
as Longcore et al. (2000) noted. Survival estimates based on band recoveries may not be reliable because so few woodcock are banded and recovery rates are low (Dwyer and Nichols 1982).

Other telemetry studies (e.g., Krementz et al. 1994, McAuley et al. 2005) have estimated PSRs during the fall and winter; however, their study locations and periods differed from those in our study. Nonetheless, survival rate estimates calculated from these studies were useful for deriving cumulative estimates to compare with our PSRs. McAuley et al. (2005) estimated survival rate from September to the end of November within the northern part of the Eastern Management Region and found no difference between hunted ( 0.636$)$ and non-hunted sites (0.661). They also estimated a weekly survival rate of 0.981 for the month of November after the hunting season ended, which equates to a November PSR of 0.925 . Krementz et al. (1994) estimated winter survival (o.647) during the period from December through February/March within the southern portion of the Eastern Management Region. Combining the non-hunted site estimate (0.661) from McAuley et al. (2005) with the winter survival estimate (0.647) from Krementz et al. (1994) provides a cumulative survival rate estimate of 0.428 from the beginning of September through February/March. Combining the November survival estimate (0.925) calculated from McAuley et al. (2005) with the Krementz et al. (1994) estimate (o.647) provides a cumulative survival rate estimate of 0.598 from November through February, a period more closely matching our study period. Both to of these cumulative estimates, -0.428 and 0.598 , respectively, -fall within the range we estimated ( 0.365 to 0.706 ) for woodcock using Cape May during November through early January.

Predation and exposure were the primary causes of mortality based on our examination of recovered woodcock. Although we could not always identify the species of predator that killed radio-marked woodcock, our post-mortem examinations indicated that avian predators were probably responsible for most deaths from preda- tion. Avian predators were extremely numerous on Cape May; with raptors likely being the most frequent cause of mortality based on evidence we observed at recovery sites (e.g., woodcock remains found below perches, talon marks in skin, piles of feathers, and stripped carcasses). Extreme weather events also contributed to mortality, particularly a severe snowstorm that occurred in late December 2010. We attributed 13 of the 22 unknown mortalities that occurred in 2010 to the late December storm. We documented no hunting mortalities during our study even 
though woodcock hunting season was open during part of the period we tracked woodcock on Cape May.

We determined that weekly emigration rates from Cape May varied by year and week within each year. There were several weeks where no marked woodcock left the peninsula, versus other weeks when as many as one-third of the marked woodcock migrated. Nearly $20 \%$ of marked woodcock (57) remained in Cape May at the end of the tracking period into January, indicating that Cape May is potentially an important over wintering area for woodcock within the Eastern Management Region; however, woodcock wintering on Cape May, however, are vulnerable to extreme storm events as occurred like that occurring in during late December 2010. Krohn and Clark (1977) reported some band recoveries from southern New Jersey during the winter, but the extent to which woodcock winter at mid-latitudes in the Eastern Woodcock Management Region is unknown.

A majority of the woodcock we tracked were hatchyear birds (Table 1). Past studies indicated a disparate age ratio of woodcock using Cape May. Haramis and McAuley (2010) used a series of towers to record the passage of VHF-marked woodcock through Cape May captured as part of the study of McAuley et al. (2005). In 1998, they detected 4 woodcock, in 1999 they detected 19 woodcock, and in 2002 they detected 20 woodcock. Only 2 woodcock landed on Cape May--; most passed over Cape May in flight. The woodcock that stopped on Cape May stayed a couple of days before emigrating.

Our study provides some of the first information about woodcock survival rates at mid-latitude stopover sites, but we were unable to assess the relation(s) between survival rates and covariates likely to influence survival rates. Potential fruitful lines of inquiry would be to evaluate relation(s) between survival rates and covariates such as body condition, habitat selection, and environmental conditions (e.g., accumulated thermal units and precipitation). Incorporating the results from the Allen et al. (2017) resource selection function (RSF) model as an individual's habitat suitability index may provide insight into the quality of habitat an individual is using. That is, if individuals using areas with greater RSF values have higher survival rates, then landscapes could be managed to increase RSF values in areas where they are currently low. For example, Allen et al. (2017) found that potential roost fields in close proximity to migratory stopover diurnal covers, in particular deciduous wetland forest, was an important factor in a woodcock's decision to select a particular diurnal cover. It would be prudent, however, to evaluate the effects of habitat selection on vital rates prior to prescribing a management action.

\section{Acknowledgments}

We are thankful for the cooperation of Cape May National Wildlife Refuge, New Jersey Division of Fish and Wildlife, New Jersey Chapter of The Nature Conservancy, and The Wetlands Institute. Thank you to our field technicians, C. Stearns, H. Jones, and J. Veale, for putting in long nights capturing woodcock followed by long days tracking them down. Thanks to B. J. Olson, J. Zydlewski, D. Dessecker, and D. Twedt for comments on an earlier version of this manuscript. Todd Arnold provided helpful suggestions for data analysis. Thanks to D. Andersen, T. Arnold, and an anonymous reviewer for their review and helpful suggestions for improving this manuscript. Funding was provided by U.S. Fish and Wildlife Service, Division of Migratory Birds, and the Maine Agricultural and Forest Experimental Station.

\section{Literature Cited}

Allen, B.B. 2017. American woodcock migration ecology at an important stopover, Cape May, New Jersey.M.S. thesis, University of Maine, Orono, Maine. 62pp.

Allen, B.B., D.G. McAuley, E.J. Blomberg. 2019. American woodcock migration ecology: factors influencing departures rates and habitat selection at Cape May, New Jersey. Page 122 in D.G. Krementz, D.E. Andersen, and T. R. Cooper, Editors. Proceedings of the Eleventh American Woodcock Symposium. University of Minnesota Libraries Publishing, Minneapolis, Minnesota, USA.

Bruggink, J.G., E.J. Oppelt, K.E. Doherty, D.E. Andersen, J. Meunier, R.S. Lutz. 2013. Fall survival of American woodcock in the western Great Lakes region. Journal of Wildlife Management 77:1021-1030.

Burnham K.P. and D.R. Anderson. 2002. Model selection and multimodel inference. Springer New York

Cooper, T.R. and J.R. Kelley. 2010. Status of American woodcock and woodcock surveys in North America. Pages 135-145 in C.A. Stewart and V.R. Frawley, eds. Proceedings of the American Woodcock Symposium 10, Michigan Department of Natural Resources, Lansing Michigan USA.

Derleth, E.L. and G.F. Sepik. 1990. Summer-fall survival of American woodcock in Maine. Journal of Wildlife Management 54:97-106.

Case D.J. and Associates (editor). 2010. Priority information needs for American woodcock: a funding strategy. Developed for the Association of Fish and Wildlife Agencies by the Migratory Shore and Upland Game Bird Support Task Force. 16pp. https://www.fws.gov/migratorybirds/pdf/surveys-and-data/ Info-Needs-American-Woodcock.pdf

Dwyer, T.J. and J.D. Nichols. 1982. Regional population inferences for the American woodcock. Pages 12-21 in T.J. Dwyer and G.L. Storm, eds. Woodcock ecology and management. Wildl. Res. Rep. 14, U.S. Fish Wildl. Serv. Washington, D.C USA.

Haramis, G.M. and D.G. McAuley. 2010. Detecting passage of migrant radio-tagged woodcock using semi-automated receiver recording equipment from fire towers. Page 109 in C.A. Stewart and V.R. Frawley, eds. Proceedings of the American Woodcock Symposium 10, Michigan Department of Natural Resources, Lansing Michigan USA.

Krementz, D.G., and J.B. Berdeen. 1997. Survival rates of American woodcock wintering in the Georgia Piedmont. Journal of Wildlife Management 61:1328-1332. 
Krementz, D.G., J.T. Seginak, and D.R. Smith. 1994. Survival rates of American woodcock wintering along the Atlantic coast. Journal of Wildlife Management 58:147-155.

Krohn, W.G., J.C. Rieffenberger, and R. Ferrigno. 1977. Fall migration of woodcock at Cape May, New Jersey. Journal of Wildlife Management 41:104-111.

Krohn, W.B., and E.R. Clark. 1977. Band-recovery distribution of eastern Maine woodcock. Wildlife Society Bulletin 5:118-122.

Krohn, W.B., F.W. Martin, and K P. Burnham. 1974. Band-recovery distribution and survival estimates of Maine woodcock. Pages 1-8 in J.H. Jenkins, W. Artmann, S.R. Pursglove, and L.O. Walker, Paper Review Committee. Proceedings of the 5th American Woodcock Workshop. University of Georgia, Athens, Georgia USA.

Longcore, J.R., D.G. McAuley, G.F. Sepik, and G.W. Pendleton. 1996. Survival of breeding male American woodcock in Maine. Canadian Journal of Zoology 74:2046-2054.

Longcore, J.R., D.G. McAuley, G.F. Sepik, and G.W. Pendleton. 2000. Survival of female American woodcock breeding in Maine. Pages 65-76 in D.G. McAuley, J.G. Bruggink and G.F. Sepik, eds. Proceedings of the Ninth American Woodcock Symposium U.S. Geological Survey, Patuxent Wildlife Research Center. Laurel, Maryland USA.

Martin, F.W. 1964. Woodcock age and sex determination from wings. Journal of Wildlife Management 28:287-293.

McAuley, D.G., J.R. Longcore, D.A. Clugston, R.B. Allen, A. Weik, S. Williamson, J. Dunn, B. Palmer, K. Evans, W. Staats, G.F. Sepik, and W. Halteman. 2005. Effects of hunting on survival of American woodcock in the Northeast. Journal of Wildlife Management 69:1565-1577.
McAuley, D.G., J.R. Longcore, D.A. Clugston, W. Halteman and G.F. Sepik. 2010. Survival of American woodcock broods and chicks in Maine. Pages 175-184 in C.A. Stewart and V.R. Frawley, eds. Proceedings of the American Woodcock Symposium 10, Michigan Department of Natural Resources, Lansing Michigan USA.

McAuley, D.G., J.R. Longcore, and G.F. Sepik. 1993. Techniques for research into woodcocks: experiences and recommendations. Pages 5-11 in J.R. Longcore and G.F. Sepik, eds. Proceedings of the Eighth Woodcock Symposium. U.S. Fish and Wildlife Service Biol. Rep. 16. Washington, D.C. USA.

Mendall, H.L., and C.M. Aldous. 1943. The ecology and management of the American woodcock. Maine Coop. Wildl. Res. Unit. . Univ. of Maine, Orono, Maine, USA.

Pace, R.M. 200o. Winter survival rates of American woodcock in south central Louisiana. Journal of Wildlife Management 64:933-939.

Powell, L.A. 2007. Approximating variance of demographic parameters using the delta method: a reference for avian biologists. The Condor 109:949-954.

Reiffenberger, J.C., and R.C. Kletzly. 1967. Woodcock nightlighting techniques and equipment. Pages 33-35 in W.H. Goudy, compiler. Woodcock Research and Management 1966. U.S. Bureau of Sport Fisheries and Wildlife Special Scientific report: Wildlife 101.

Seamans, M.E., and R.D. Rau. 2016. American woodcock population status, 2016. U.S. Fish and Wildlife Service, Laurel, Maryland. USA.

White, G.C. and K.B. Burnham. 1999. Program Mark: survival estimation from populations of marked animals. Bird Study 46.

White, G.C., W.L. Kendall, and R.J. Barker. 2006. Multistate survival models and their extensions in program MARK. The Journal of Wildlife Management 70:1521-1529. 